\title{
A Song and Dance: \\ Branded entertainment and mobile promotion
}

Paul Grainge

\begin{abstract}
This article considers the rise of branded entertainment within the contemporary marketing and media environment. Specifically, it examines how mobile phone marketing in the UK has sought to engage consumers, and perform the social use of mobile technology, through multimedia ad campaigns with an inscribed entertainment value. Focusing on brand campaigns for $3 \mathrm{G}$ mobile services that borrow explicitly from reality television (T-Mobile) and Hollywood film (Orange), the article explores the concept of branded entertainment in relation to the 'popular imagination' of mobile communication in the late 2000 s. In doing so, it examines the particular relation of flash mobs to the production of brand community.
\end{abstract}

\section{Keywords}

Branding, entertainment, mobile phones, flash mobs, performance, digital media, affect

In 2003 the New York Times took notice of a trend occurring in various North American and European cities that year - the fad or phenomenon of 'flash mobs' (Walker, 2003: SM11). Describing groups of 'well-wired folks who gather suddenly, perform some specific but innocuous act, then promptly scatter,' the feature pondered the significance of these 
idiosyncratic public happenings, in particular their co-ordination through websites and mobile phones. Fending off those who dismissed the trend as the 'technological equivalent of streaking,' the feature borrowed from Howard Rheingold (2002) in making a case for their cultural significance, specifically the way that flash mobs 'make networks tangible.' Regarded as a new expression of connectivity, the article also described the fear among bloggers that 'flash mobs are going to be hijacked, most likely by consumer companies' (Walker, 2003: SM11). In the UK, this moment can be dated precisely and came in the form of a multimedia brand campaign for the mobile telephone operator T-Mobile, owned by Deutsche Telekom. On 16 January 2009, T-Mobile launched a promotional campaign on television and YouTube that literally performed the company's brand slogan 'Life's for Sharing.' This took the form of a spontaneous dance routine in the main concourse of Liverpool Street Station in London. Staged during the previous day's rush hour and shot through ten hidden cameras, the routine began with the movement of a single disguised commuter, and would build to include 350 dancers all performing in sync to a medley of classic and contemporary chart hits before suddenly stopping and dissolving into the assembled crowd. Spectacular in its display of rhythmic synchronization and impromptu sociality, the advert dwelling on those moments where unsuspecting members of the public joined in the performance, 'the dance' became an immediate television talking point and YouTube hit.

In brand terms, the flash mob was the first of several choreographed public events by T-Mobile designed to animate the nature and potential of social relationships in a digital age, especially those enabled by cellular technologies. Connecting mobile users to performances within urban space, the 'Life's for Sharing' campaign was based on a number 
of live performances that made virtual communities physically present. This would also involve an ad featuring a mass sing-a-long by thousands alerted to the event by web and text and a series of advertisements following an aspiring musician, Josh Ward, in his attempt to put together a band using free texts and internet through his mobile phone. The ongoing promotion of 'Josh's band' included TV ads showing Josh recruiting members of the public at gigs in various British cities, and culminated in a three-minute advertisement featuring the song itself, 'Come With Me,' performed by 1,107 band volunteers. With neat marketing shape, the ad premiered exactly a year after the flash mob. According to Adam Arvidsson, 'one of the most important and fundamental trends in contemporary consumer society is the progressive inclusion of consumers in the processes where value is produced around products and brands' (2008: 326). This trend was clearly demonstrated by T-Mobile in its ambition to connect mobile users; it developed an integrated media campaign that used television and new media to facilitate the work of brand community building. 'Life's for Sharing' relied centrally on different kinds of mobile, and promotionally mobilized, screen performance. According to the agency responsible, Saatchi \& Saatchi, the aim of the campaign across its various articulations was 'to create an event that people would want to take part in and then share with each other' (Saatchi \& Saatchi, 2009).

The T-Mobile campaign exemplifies the tendency within current brand thinking to enlist consumers as creative participants in the advertising and marketing process. More generally, however, it demonstrates the rise of branded entertainment within contemporary media culture. In distinguishing post-network advertising strategies, Amanda Lotz suggests that 'branded entertainment marks a fundamental shift from intrusive advertisements pushed at audiences who are engaged in other content to advertising of such merit or 
interest that the audience actively seeks it out' (Lotz, 2007: 172). ${ }^{1}$ The extent to which branded entertainment differs from traditional advertising methods is contestable. However, anxiety about the effectiveness of conventional spot advertising has inspired trade theorizing about promotional alternatives, inspiring calls for greater convergence between the advertising and entertainment industries (Donaton, 2004). Responding to a fragmented media environment where audiences have become more fugitive in their viewing habits and able through digital video technologies to make choices about which commercials to watch and which to skip, branded entertainment extends advertiser involvement in the production and authorship of content. Unlike sponsorship and product placement which affiliates brands with existing film and television vehicles, branded entertainment involves the creation of content that contextualizes 'brand images in ways that are so appealing that consumers will seek them out for inclusion in their personalized media and entertainment flows' (Spurgeon, 2008: 40).

This article examines how strategies of branded entertainment have been deployed in the selling of mobile phones, in particular third generation (3G) mobiles that have the capacity to deliver multimedia/data services through high-speed broadband internet access. The practice of branded entertainment and the phenomenon of web-enabled mobile communication both took hold in the 2000s. Taken together, they help to think about developments in media promotion within convergence culture. If, as Christina Spurgeon suggests, branded entertainment 'can be understood as an important creative response to the growth of search culture' (2008: 39), branded entertainment illustrates the way that marketers have sought to co-link entertainment content with new technological infrastructures to give brands greater credibility, interactivity, and depth of appeal. The 
strategies of branded entertainment used by mobile operators provide a vantage on what Henry Jenkins calls the 'affective economics' of the contemporary marketing and media environment (Jenkins, 2006: 61-2).

In a different sense, the branded entertainment developed by telecommunication companies can help illuminate the promotion of media in the mid-to-late 2000 s, specifically the 'popular imagination' of mobile technology in this period. According to William Boddy, moments of transition within media history such as the arrival of digital audiovisual technologies are significant not only for what they reveal about 'technological innovation, market restructuring, and changes in traditional representational practices' (2004: 2) but also for what they produce in a vernacular and imaginative sense. He suggests that by looking at self-representations of media technology, not least in the ephemera of TV commercials, it is possible to uncover the 'strategic fantasies of consumption that can speak eloquently of the larger cultural ambivalence regarding new communications technologies' (ibid: 1). Mobile phone advertising is especially significant in this respect. While the TMobile flash mob mobilized a set of fantasies for UK audiences around the experience of life sharing, this departed from a series of smart ads by rival company Orange which, as part of its national 'Orange Wednesday' cinema promotion, parodied film pitch sessions using a range of Hollywood stars to promote mobile etiquette in movie theatres. Both used television, cinema and new media platforms to create brand campaigns with an inscribed entertainment value. However, they linked mobile technology to different scenarios of public space and social behaviour. Within the critical terms of this article, the two campaigns exemplify the mobilization of brand advertising as screen entertainment, but 
also illustrate what Boddy calls 'the dream life' of electronic media in the first decade of the twenty-first century.

\section{Mobile promotion: entertaining 3G}

The advertising strategies used to sell mobile phones vary within and between markets. Promotional approaches are shaped in place and time by market specific factors such as the technological and network capabilities of particular regions, habits of mobile use among populations (variously defined by age, vocation and socio-economic status), the brand identity of mobile operators and handset producers in global and local contexts, and the

more general role of advertising as a cultural practice with specific territories and locales. ${ }^{2}$ China, as the largest cell-phone market in the world, saw mobile advertising assume a distinctly national inflection in the 2000s, Chinese handset companies such as Ningbo Bird associating their name with national Olympic champions to compete with Western brands like Motorola, Nokia and Sony Ericsson for dominance of the low-end mobile market (Spurgeon, 2008: 75). In the same period, advertising in other major markets envisioned the social and technological affordances of mobile communication through a variety of lifestyle images. These were often accompanied by recurring visual motifs. For example, as mobile phones moved from being thought of as a communication technology to a screen device able to wed sound and image, promotional imagery in the early 2000s saw mobiles in European and American markets associated with the act of looking. Heidi Rae Cooley observes this tendency in various US ads where human eyes peer from mobile LCD screens or where hands, and the act of holding a mobile, are associated with seeing (Rae Cooley, 
2004). While camera phones would accentuate this sense of 'tactile vision,' mobile MP3 functions would give rise to images of transported listening within urban environments. With the establishment of third generation networks in developed Western markets, and the subsequent launch of mobile television and other advanced data services, a growing number of ads in the latter half of the 2000s presented mobile phones as a medium for audiovisual content, mobile screens frequently displaying clips from high-profile Hollywood content. ${ }^{3}$ Whether portrayed as a technology for looking, listening, talking, texting, viewing, or video-enabled browsing, mobiles have been imagined to possess, at least within affluent urban markets, a transforming influence on projections of self, audiovisual sense, and, not infrequently, cityspace. These selective examples barely scratch the surface of the manifold and culturally variable ways in which mobile phones have been imagined in marketing terms. They point broadly, however, to conjunctures where promoters of new media technology have connected technological innovation with compelling scenarios of identity, communication and behaviour.

Branded entertainment is a particular means of delivering these scenarios to consumers. Rather than focus on a sales-driven message, key to the short-term economic metrics of conventional advertising, branded entertainment is designed to build long-term relationships with consumers and deepen brand loyalties among targeted groups. Although the practice remains a small segment of the creative output of the advertising industry, strategies of branded entertainment have become a front in the attempt by marketers to create emotional relationships with consumers and to enlist their affective labour in adding value to the qualities of a brand within everyday communication. Brand messaging is herein loosened from interruptive styles of commercial sales and product integration, and seeks 
instead to engage audiences by providing, or enabling participation within, an

entertainment experience. According to Steve Marrs, CEO of Brand Entertainment Studios, a New York-based consultancy launched in 2002: 'If you can create an environment that is entertaining to your desired consumers and allows them to be entertained in the context of the brand, then you have an ideal form of communication with your consumer that is relevant, original and impactful' (cited in Hespos, 2003). The idea of fashioning entertainment 'in the context of the brand' returns us to the T-Mobile flash mob and the 'Life's for Sharing' campaign. Not only did the Liverpool Street flash mob transform a public environment into a site for 'impactful' entertainment - a dance spectacle duly circulated with its own teaser, trailer and making-of documentary - it more importantly formed the basis of an extended performance event within the wider environment of converged media.

The T-Mobile flash mob was one of many brand campaigns to promote mobile phones in the UK. However it was particularly significant both in its iconic appeal and as it was situated against the backdrop of the regulatory thrust of UK government policy on digital life in the late 2000s. In January 2009, the same month as the Liverpool Street flash mob, a major government report was published called Digital Britain. This would be followed by a lengthier final report in June that laid out plans for developing digital infrastructure and participation in the UK. Seeking 'to secure the UK's position as one of the world's leading digital knowledge economies' (Carter, 2009: 7), the Digital Britain report proposed policy measures for developing the communications infrastructure of the UK and for enabling the wider social, cultural and economic potentialities of 'being digital.' For the mobile industry, this included recommendations for maximizing mobile and wireless networks, part of the Government's drive to achieve universal coverage for 3G mobile 
broadband through the allocation of spectrum licenses and schemes of network sharing. The UK has a solid infrastructure for mobile broadband equivalent to counterparts in the developed world. Following the government auction of the $3 \mathrm{G}$ spectrum in the UK in 2000 , mobile broadband coverage in the UK had reached $90 \%$ by the end of 2008 , directly comparable with the US $92.3 \%$, Italy $92 \%$ and Norway $90 \%$, although less than Korea $99 \%$, Australia 99\%, Sweden 100\%, and Japan 100\% (OECD, 2010). However, it remained the case that only $17 \%$ of mobile users in the UK were on $3 G$ when the report appeared. With the Government eager to maintain the position of the UK 'on the leading edge of the new mobile revolution' (Carter, 2009: 74), the T-Mobile ads contributed to a wider set of cultural and promotional discourses surrounding $3 \mathrm{G}$ mobile communication. The campaign created a self-serving fantasy of $3 \mathrm{G}$ mobile technology that, to borrow from William Boddy, 'illuminates the larger contexts and implicit assumptions which frame both public policy and private consumption' (2004:1).

The transition to $3 \mathrm{G}$ became a source of wide-ranging policy discussion in the 2000 s. The launch of the first commercial 3G service in Japan in 2001 and South Korea in 2002, followed by the introduction of 3 G networks in Europe and the US in 2003, was underpinned by policy protocols about the standards required for wireless communication, as well as (ongoing) competition policy rules governing the activities of mobile operators and the cost of licence fees within particular regional markets (see Tilson and Lyytinen, 2006; Bjorkdahl and Brolin, 2003). While the development of $3 \mathrm{G}$ mobile communication intersects with the Digital Britain report at the end of the 2000s, it is important to note that the technological and political trajectory of $3 \mathrm{G}$ has a longer history dating back to the launch of the first web-enabled phone in 1999 and, in the European context, to wider attempts by 
the EU to establish the necessary standards and regulatory systems to create convenient, reliable, telecoms networks and services for a pan-European market.

These policy initiatives frequently sought to maximize the potential of $3 \mathrm{G}$ to deliver application services such as mobile internet access and mobile TV. The development of mobile communication in the 2000 s focused, in no small part, on the capacity of $3 G$ phones to function as an entertainment platform. For example, in order to speed up the rollout of standards that would enable mobile television services, the European Commission published a legal framework and set of guidelines in 2008 designed 'to get mobile TV on Europeans' mobile phones' (EC, 2008). The use of branded entertainment within mobile advertising and promotion is consistent with this attempt to facilitate and re-imagine the mobile phone as a device that can offer new possibilities for online and audiovisual consumption.

The T-Mobile campaign was one of a number of texts to reflect a shift in the meaning of the mobile phone as an interface in the mid-to-late 2000s (May and Hearn, 2005). It not only cast the mobile phone as a prospective entertainment platform, but also produced shareable media content that drew attention to the 'mobilization' of public space. The development of $3 G$ networks and the diffusion of web-enabled phones required marketing discourse to reconceptualize the type of social relationships and spaces that mobile phones mediate. Adriana de Souza e Silva suggests: 'Because mobile devices create a more dynamic relationship with the Internet, embedding it in outdoor, everyday activities, we can no longer address the disconnection between physical and digital spaces' (de Souza e Silva, 2006: 262). She argues that in allowing users to be constantly connected to the internet, even while walking, mobile phones enable virtual communities to migrate to 
physical spaces. Ever since texting emerged in the mid-1990s, mobile mass communication has enabled people to exchange information with the purpose of co-ordinating face-to-face gatherings - social, political or otherwise. The connectivity of digital mobile media has expanded the possibilities of virtual and corporeal communication, however.

The practice of bringing social networks into co-present space would become a prominent feature of the 'Josh's band' campaign for T-Mobile. Promoting free unlimited text and internet access, television and new media advertising encouraged people to translate their virtual interest in Josh's musical quest - fostered through a dedicated Twitter feed, MySpace page and YouTube channel - into physical jamming sessions in London, Manchester, Birmingham and Edinburgh. In the marketing sequence of the 'Life's for Sharing' campaign, 'Josh's band' built on two promotional flash mobs designed to elevate TMobile's brand status. The first of these saw the aforementioned dance in Liverpool Street Station and the second, four months later, involved a mass karaoke event in Trafalgar Square where a reported 13,000 people gathered to sing the Beatles' 'Hey Jude' and Pink's 'So What' (where she also appeared) after T-Mobile corralled people by text and through a YouTube video carrying the message: 'Remember the dance? Want to be part of the next event? Be at Trafalgar Square. This Thursday. April 30th 6pm-7pm.' Over the course of twelve months, the 'Life's for Sharing' campaign unfurled as a series of synchronized performances, all involving the public and with progressively deliberate integrations of mobile technology into mediated acts, and events, of social production.

According to T-Mobile's chief marketing officer Srini Gopalan, 'the flash mob ads were part of a strategy to build an emotional connection with consumers by using real people to give the campaign an element of a Big Brother-style reality television programme' 
(Costa, 2010). The reference to Big Brother is consistent with mobile phone marketing strategy in the UK; reality formats that rely on phone and text voting such as Big Brother and The $X$ Factor are routinely sponsored by mobile retailers/networks and have been used as a platform for consumers to interact with particular sponsorship campaigns. For example, a campaign for Carphone Warehouse/TalkTalk in 2009 built around The X Factor invited viewers to record their own online singing performances via a webcam, the resulting videos forming the basis for a series of TV ads. T-Mobile took this principle of audience involvement a step further, moving beyond user-generated break bumpers towards television and online video content with its own 'crowdsourced' entertainment value. This strategy tapped the peer-to-peer opportunities for social production that have evolved around networked communication technologies. If, as is widely theorized, 'new media environments extend the possibilities for conversational interaction and participation, and generate new possibilities for consumer productivity' (Spurgeon, 2008: 7; see also Jenkins, 2006), marketing has sought to capitalize on these participatory dynamics. This entails for corporate brands and the agencies who sell them expertise 'the diversification and integration of the range of techniques for facilitating advertiser-consumer interaction' (ibid: 104).

The 'Life's for Sharing' campaign is a clear example of the ways in which marketers have sought to build brand communities by connecting television, cinema and print advertising to the conversational possibilities of digital media. According to Lysa Hardy, head of brand communication at T-Mobile, 'the industry sees its future in mobile data so we should use it more to bring campaigns to life' (Farber, 2009). Srini Gopalan concurred: 'If we're a brand that is about participation and sharing, then we need to drive real mass- 
market mobile internet. The Android platform is starting to make mass-market mobile internet more accessible, and out of that will come social networking and the related brand values' (Costa, 2010). These statements demonstrate the impetus to connect $3 \mathrm{G}$ mobile technology with new marketing approaches that emphasise consumer interaction and social participation. They also implicitly support Will Brooker's argument that mobile phone advertising offers a 'kind of training' about the digital world. Brooker suggests that narratives of contemporary popular media, including the mini-narratives of advertising, 'teach their viewers the gestures and language, the possibilities and advantages of technology, but also, crucially, they enforce the social importance and status of mastering the world-as-data' (Brooker, 2010: 553). He contends that popular entertainment has a tutorial function within twenty-first century capitalism, helping audiences to acquire the attitudes, understanding and mentality necessary to live in a world of digital media. Whether the T-Mobile ads were, in fact, tutorials for audiences or whether audiences offered tutorials for marketers in the co-production of brand community, T-Mobile's realitystyle campaign resonated with the call of Digital Britain 'to put people at the centre of all our digital thinking' (Carter, 2009: 27, my italics); it aestheticized the idea that 'being digital' was a vital source of connectivity, creativity and communal participation. According to Digital Britain, 'Digital technology is no longer simply desirable. It is rapidly becoming an essential facility to citizens and consumers in a modern society' (ibid: 28). With phones reconceived as personal computers able to send and receive data, mobile communication has been figured within promotional discourse as central to the performance and orchestration of contemporary living. Anxious for consumers to entertain 3G, mobile operators have used screen entertainment to elicit emotion around new potential ways of 
seeing, acting and thinking. Flash mobs in this context are a scene upon which fantasies of the social function of mobile technology have been performed for, and by, British audiences.

\section{Mobile performance: flash mobs and film pitches}

Mobile communication is often experienced as disruptive within public space and everyday life, from the common frustration of phones going off at inappropriate times and places to the pedestrian hazards of people simultaneously talking, walking and checking their screens (Ling and Donner 2009: 107-112). The Liverpool Street flash mob offered a different scenario of social interaction, however, one that was thrilling, and even potentially moving, to watch. The flash mob attracted 3.5 million hits on YouTube within three weeks of its launch. During this time the 'Life's for Sharing' channel became the most highly subscribed channel on YouTube in the UK. In creating 'an event that people would want to take part in and then share with each other,' the performance of the crowd was central to the ad's affective currency. In accounting for this it is useful to reconsider the flash mob as a peculiarly contemporary cultural form.

As a practice, flash mobs were shaped in the late 1990 s and early 2000 s by the popularity of texting which could facilitate rapid, decentralized, one-to-many communication. As previously mentioned, flash mobs became briefly emblematic of mobile connectivity in 2003 , leading to a number of stunts in cities like New York, London, and Berlin that assumed the status of performance art. These would see groups quickly assemble to perform a random public act and then disband, leaving onlookers bemused. In 
a useful summary of its political and artistic inclinations, Judith A. Nicholson writes that 'flash mobbing straddled the boundaries between spectacle, activism, experiment and prank' (2005). Situated in a political climate where crowds and public places had become associated with terrorist intent, and where mobile and internet traffic was increasingly subject to state and commercial surveillance, Nicholson draws out the ideological ramifications of people being able very quickly to transform public space, whether to protest or, as a popular flash mob credo proclaimed, 'in the pursuit of nothing.' The TMobile dance echoed a planned flash mob in New York's Grand Central Station in 2003. Where this particular 'mob ballet' had been cancelled due to concerns about the potentially twitchy response of armed law enforcement officials, the T-Mobile flash mob was suggestive of the way that corporate marketers and television executives had by 2009 transformed the practice into something popular and mainstream. ${ }^{4}$

My interest here is less the manner in which advertising appropriated the form of the flash mob, or co-opted its potential for quasi-Situationist critique, than the particular means by which mobbing was turned into screen entertainment and put to imaginative work. In style and occasion the Liverpool Street Station flash mob borrowed less from performance art and more from street theatre. By creating surprise entertainment in the flux and flow of the city, Sally Harrison-Pepper suggests that street performance has the capacity to present 'alternatives to the existing system of governance or conventional ways of living' $(1991,12)$; it often relies on unauthorized expressions within public space which, through laughter or amazement, can jolt people out of their daily routines. Although the TMobile dance was an extensively rehearsed and pre-planned stunt, facilitated by the offices of Film London, it nevertheless inscribed a sense of alternative urban potential. Its affective 
power was a function of dance choreography but also, I would contend, of civic communication. However limited and transitory this may have been, the flash mob represented a form of communing that was leaderless, wordless, concerned with popular culture as well as spontaneous and collective. If, as Judith Nicholson suggests, 'flash mobbing may be interpreted as a commentary or reflection on contemporary spaces and routines' (Nicholson, 2005), the T-Mobile dance re-imagined the space, routine and sociality of the guarded urban crowd.

Following the terrorist attacks in New York, Madrid and London in the early 2000s, train stations became, and have remained, a site of heightened CCTV surveillance, cameras monitoring suspicious objects, people and behaviour. Ironically in this case, cameras were hidden in suitcases and vending machines to capture a crowd acting suddenly, and serendipitously, against the norm. The flash mob involved disguised dancers of all ages performing a routine that moved with fluid gear-shifts between eight tracks with broad cross-generational appeal. This included music by Lulu ('Shout'), Yazz ('The Only Way is Up'), The Pussycat Dolls ('Don't Cha'), Strauss ('Beautiful Blue Danube'), Kool and the Gang ('Get Down on it'), Rainbow ('Since You've Been Gone'), Millie ('My Boy Lollipop') and The Contours ('Do You Love Me'). Switching between panning shots of the synchronized routine and close-ups of bystanders watching, taking pictures on their phones, laughing into their mobiles, and actually joining in, the ad seized upon moments of shared sociality in a space more often characterized by the passing and policing of strangers. This was reinforced in ancillary videos released on YouTube where interviews with members of the public described the event as 'delightful,' 'contagious' and 'a moment of love.' 
The dance was designed to capture attention within the television schedule and to appeal in ways that encouraged audiences to seek out and watch the performance again. Conceived as branded entertainment, the Liverpool Street 'dance' and the Trafalgar Square 'song' were released with the apparatus of reality television promotion. This included online teasers about the coming live event, making-of documentaries showing the auditioning and filming process, and bonus material featuring off-screen interviews and performances. Fostering fan re-enactment, T-Mobile also posted branded 'how to' videos breaking down the moves of the dance routine. These instructional videos formed the basis of several amateur re-enactments of the flash mob in British shopping malls, demonstrating the strategic potential of dance to engage the productive potential of ordinary consumers. Given the popularity of amateur home dance videos on YouTube and their opportunity for 'public self-thematization' (Peters and Seier, 2009: 188), dance was especially geared to the viral environment and to the launch of an aspiring online campaign.

Within marketing terms, dance and musical performance offered a particular valuebasis for T-Mobile to facilitate consumer interaction and attract free labour. Adam Arvidsson calls this the 'ethical economy of customer co-production' (2008). He writes that in a fragmented social environment where durable ties are scarce, 'promoters thrive by giving affective strength, for a short time at least, to what are essentially weak ties between participants in a scene. These ties entail commitment, trust and solidarity - that is, they are experienced as ethically significant' (2008: 333). The 'Life's for Sharing' campaign exemplifies this giving of affective strength. By the terms of Arvidsson's argument, value for participants is not primarily of the product but of the process - and in this case the performance - that allows them 'to have their efforts socially recognized as creative, 
inventive or beautiful in a sustained way' (ibid: 333). In turn, value for marketers is in rationalizing media promotion, mining and surveying cheap labour to create a community of productive viewers who can be recruited to participate in what Mark Andrejevic, describing the modus of reality television, calls 'the work of being watched' (2003). 'Josh's band' would especially capture the contradictions of user-generated labour, offering people 'a modicum of control over the product of their creative activity in exchange for the work they do in building up online community and sociality upon privately controlled network infrastructures' (Andrejevic, 2009: 419). ${ }^{5}$ Whatever the stakes of agency and exploitation in the example of 'Josh's band,' the 'Life's for Sharing' campaign was based on the (seemingly) spontaneous production of community. In doing so, it mobilized screen performance in reality-based content that used the history of pop music and hip flash mob aesthetics to cross the demographic line between teens, twenty-somethings and older middle markets.

As a point of comparison, it is worth considering how this demographic line was crossed in a different mobile campaign that used film as a basis for branded entertainment. While T-Mobile used reality content to engage its market audience, in particular young mobile users, the campaign of Orange, then a major network competitor owned by France Telecom, took an alternative approach. Since 1996, Orange has run a multi-faceted campaign connecting its brand to film entertainment. In 2009, this included sponsorship of the Baftas, a dedicated award (the Orange Rising Star Award celebrating young actors), a short film competition ('60 Seconds of Fame' inviting anybody to create and upload a short film to the Orange website, the winner shown at the Baftas), and a signature initiative called 'Orange Wednesday' that allows Orange phone customers to buy two cinema tickets for the price of one across the UK on Wednesdays. According to Hattie Magee, head of brand 
partnerships at Orange UK, 'Within the entertainment space, film has very broad appeal and will be attractive to many different audiences. It offers us not just youth but an older age demographic. As we have a very wide customer base, it has always been a very appropriate medium for us' (Hosea, 2008: 48). This focus on cinema has led Orange to position itself as a sponsor of the film industry but also as a self-reflexive film producer.

This status is crystallized in branded content (so-called 'golden spots') shown before the ad sequence of UK cinema screenings. Since 2003, these have become part of the ritual of movie-going in the UK and have become entertainments in themselves. The spots involve a film pitch by a Hollywood actor to the 'Orange Film Commission Board,' chaired by the comedy writer Steve Furst. In each case, the executives of the board crudely attempt to leverage mobile-related ideas such as texting or the colour orange into the movie concept. This is met with incredulity and weary resignation by the talent giving the pitch. The spots have featured Snoop Dogg, Maccauley Culkin, Michael Madsen, Val Kilmer, Patrick Swayze, Mena Suvari, Steven Seagal, Sean Astin, Carrie Fisher, Angelica Huston, Roy Scheider, Verne Troyer, Darth Vader (in character), and Spike Lee. Playing with and against their respective star personas, the ads enact a different kind of mobile screen performance to that of TMobile, turning what John Caldwell calls the 'industrial performance art of pitching' (2008: 84) into a parody of crassness. While high concept pitching has often been viewed negatively in these very terms, the Orange ads make sport of mobile marketers rather than the contemporary studio system. Accordingly, the spots end with the admonishment: 'Don't let a mobile phone ruin your movie. Please switch it off.' Hattie Magee explains of the ads: 'What is key, creatively, is that it has to add to the cinema experience, so that it is not a direct piece of advertising, just selling products. The tongue-in-cheek content is very much 
about how brands can ruin films' (Hosea 2008: 48). This form of self mockery is consistent with Orange's own brand identity; in laying bare the intrusions of mobiles and commerce within social and artistic life, Orange is able to reinforce the sense of cultural capital - of knowing what to like and how to behave - that the company nurtures more generally within its marketing.

Rather than equate its brand with reality television, Orange has aligned itself with the cultural value of cinema. Within the 'golden spots,' this is directed towards generational nostalgia for Hollywood's recent movie past. From A Clockwork Orange (1971) and Jaws (1976) to Reservoir Dogs (1992) and Lord of the Rings (2001-03), the Orange ads engage various demographic and taste constituencies through their film referencing. Like T-Mobile, Orange speaks to different audience segments through its use of popular culture. The ironic interplay with Hollywood stars also distinguishes Orange in brand terms, however. Steering away from explicit sales propositions, or ads that show mobile phones, the Orange spots establish cachet through their humorous wink to popular film knowledge, inviting audiences to get the film reference and hence the joke. Through different means, Orange positioned itself at the end of the 2000s as the brand custodian of British cinema-going, connecting mobile phones to contemporary movie literacy and leisure activity.

The promotional association that Orange has forged with film, both in arts sponsorship and branded content, produced a different vernacular around $3 \mathrm{G}$ mobile communication. Instead of the rhetoric of sharing, Orange reinforced a sense of distinction in the protocols and possibilities of mobile use. At one level, Orange developed the idea that using mobile phones requires savoir-faire; attentive to anxieties about their potential for disturbance within public (cinema) space, Orange became a champion of mobile etiquette. 
At a more tactical level, film offered a means of promoting the consumption of movies within and beyond the multiplex; Orange connected its brand to particular handsets such as the Sony Ericsson Satio that were advertised as 'the ultimate phone for film lovers.' In both examples, Orange sought to insert itself within taste hierarchies that translated popular cinephilia for a digital age. This was consistent with the company's own strategic response to the shifting meaning of mobile phones as technology, interface and medium. As Magee explained, anticipating Orange's cinema-focused website, iPhone app and Facebook film club, 'We have moved away from being about just text and talk. We're a brand that offers multiple services. Film is a platform to help us communicate some of these multimedia products and services' (Hosea, 2008: 48). Where T-Mobile became a locus of cultural activity as the co-producer of reality entertainment, Orange became a taste-maker for mobileowning film communities, mediating relationships between movie audiences and the biggest and smallest of screens. In each case, T-Mobile and Orange demonstrate how telecommunication campaigns have used entertainment to enact scenarios and performances of mobile living, marked in a period where the dream life of connectivity - of being 'effortlessly digital' to quote internal marketing language at Orange ${ }^{6}$ - had become a commercial, as well as a governmental, priority.

\section{Conclusion: effortlessly digital?}

If promotional materials help uncover the 'fantasies of consumption that can speak eloquently of the larger cultural ambivalence regarding new communications technologies' (Boddy, 2004: 1), it is necessary to conclude by asking what ambivalence, if any, is evidenced 
by the kinds of branded entertainment used by mobile phone operators in the mid-to-late 2000s? Most immediately, I would argue that branded entertainment suggests ambivalence within the marketing industry itself about the impact of new communications technologies on media promotion. Although announcements about the death of the thirty-second commercial are premature, interruptive pedagogies of advertising practice have been challenged in a multimedia environment overflowing with information, advertising and content choice. In large part, the inception of branded entertainment is a response by the advertising industry to a digital search culture that has unsettled promotional methods and business models based on spot commercials. Whether assuming the conventions of reality television, comic shorts, action movies, or produced as long-form ads, branded entertainment is dually encoded as advertising and entertainment; it encourages audiences to seek out promotional content for pleasure or as a cultural resource for identity projects (see Kennedy, 2009; Grainge, 2010). The significance of branded entertainment within marketing practice should not be overstated, but neither should it be regarded simply as an old method with a new name. In industrial, aesthetic and affective terms it has become a vehicle for re-conceptualizing the space of the commercial break, the status of advertising as cultural form, and the style of engagement between consumers and brands (Grainge, 2008: 39-43).

Initially associated with experiments in niche marketing by automotive brands such as BMW, Mercedes, and Ford, the growing impetus to build communities around branded content made it attractive to companies with a stake in networked, peer-to-peer communication. As mobile phones were increasingly transformed into devices for sharing and delivering digital content, network operators were drawn to promotional strategies that 
could illustrate and contextualize this potential. Branded entertainment became a way for companies such as T-Mobile and Orange to promote the multimedia and entertainment features of mobile phones. Despite their different advertising and market inflections, TMobile and Orange shared overlapping concerns in this respect; they both sought to create fantasies about the social, cultural and audiovisual possibilities of mobile data. As I have shown, this involved particular kinds of brand performance.

Amidst the fervour of their respective campaigns, however, was a nagging ambivalence about the social role of mobile technology. While Orange explicitly lampooned breaches of mobile etiquette, T-Mobile gave tacit acknowledgment of the economic divisions and gendering of 3G mobile ownership, a subsequent 'Life's for Sharing' poster depicting a smiling forty-something woman with the message 'who says a smartphone with apps can't be available to everyone?' This addressed the implicit assumption that $3 \mathrm{G}$ phones were for a certain kind of consumer in the late 2000s, predominantly affluent, gadget-loving men. In the rhetoric of the campaign, it was one of a number of underlying cultural ambivalences that coalesced around the principle of sharing.

These ambivalences were brought home in political and economic terms. Indeed, while T-Mobile was conducting its song and dance in 2009, 'Life's for Sharing' assumed an unexpected legal and regulatory meaning. Firstly, it was discovered that T-Mobile staff had unlawfully sold private data from thousands of customers to third-party brokers. This trade in personal records raised issues of data protection and posed an altogether different set of questions about life sharing: namely whose life is being shared, by whom, for whom, and with what consequences for digital privacy rights? Secondly, just as 'Josh's band' was gathering steam, T-Mobile UK and Orange UK announced plans to merge. If permitted by 
the European Commission and UK Office of Fair Trading, their merger would create the largest mobile phone operator in the UK, with 29.5 million customers and a combined market share of $37 \%$, significantly ahead of its nearest rivals Vodafone (27\%) and 02 (25\%). It would also mean that the merged company would hold $84 \%$ of the strategic $1800 \mathrm{MHz}$ spectrum band, key to enabling fourth generation $(4 \mathrm{G})$ wireless technologies. For rival mobile operators, this flew in the face of a government settlement designed to ensure the spectrum was allocated fairly between competitors. While the agenda of Digital Britain was to facilitate industry conditions for broadband access to all homes by 2012, it seemed, momentarily, that network sharing was not for life. In March 2010, the merger between TMobile and Orange was approved but only after the firms agreed to give up bandwidth.

These regulatory and industrial flashpoints provide an appropriate coda to this article's consideration of the promotion and popular imagination of mobile communication in the UK. William Boddy suggests that the 'unique legal and political relationship of electronic media industries to the state in the USA and elsewhere has sensitized the major corporate actors to the strategic importance of being able to define the electronic media's ontologies, audience demands and social rationale' (2004: 4). Within developed markets such as Britain, the vernacular of mobile communication in the mid-to-late 2000 s was built around fantasies of cultural and network connectivity, the prospects of which were elaborated in content forms that strategically - although not unambiguously - promoted the corporate-political agenda of harnessing digital technologies for new ways of living. The TMobile flash mobs and the Orange film pitches were performance spectacles in this context. Set against a backdrop of corporate re-alignment and public policy discussion surrounding the digital economy, they provided scenes upon which popular hopes and anxieties around 
mobile communication were played out. Promotionally mobilized as screen entertainment, they illustrate how in social and market terms, within the UK and beyond, becoming 'effortlessly digital' has required, and will continue to require, significant imaginative as well as infrastructural work.

\section{Notes}

${ }^{1}$ Automobile promotion has been a test-bed for these strategies. In 2001, Ford invested $\$ 6.5$ million on No Boundaries, a thirteen-part series named after its own brand slogan broadcast on the WB network. In the same year BMW launched The Hire, an online series of branded film shorts which Mercedes later aped with a faux trailer called Lucky Star (2002). Meanwhile Honda has made a number of distinctive ads such as Honda Cog (2003) that have developed extended afterlives on YouTube.

${ }^{2}$ In case specific terms, the UK has one of the largest mobile markets in Europe, both in revenue and in the number of subscribers (76 million in 2009). The UK is served the time of writing by five major providers which had all launched $3 G$ services by the late 2000 s:

Orange, Vodafone, $\mathrm{O} 2, \mathrm{~T}-$ Mobile and 3. This highly competitive market has required companies in the UK to differentiate their network packages but also their brand identities in very deliberate terms.

${ }^{3}$ This article is principally concerned with the promotion of mobile phones rather than ways in which mobile phones have been used for promotion. It should be noted, however, that the development of mobile phone content/advertising has become a growth field. This 
ranges from the sale of customisable ring-tones and the circulation of games, mobisodes and ad-supported mobile services, to the sending of promotional messages to idle screens. Mobiles have become central to trade discussion about online advertising in these respects, including issues of targeting, metrication and, in the case of mobisodes, small screen aesthetics (Dawson, 2007; Evans, 2011).

${ }^{4}$ Flash mobs became something of a television fad in 2009 and 2010 . The mob dance style featured in episodes of US programmes ranging from Glee (Fox, 2009) to Modern Family (ABC, 2009), and formed the basis of UK channel idents and TV promos inspired by, and surrounding, dance-based reality shows such as Got to Dance (Sky 1, 2010) and Strictly Come Dancing (BBC One, 2010).

5 'Josh's band' purportedly developed as a challenge to a random member of the public when asked by a T-Mobile film crew what he would do with free texts and internet for life. Unlike the song and dance flash mobs, the grassroots credentials of this marketing conceit was received more sceptically within critical and web discussion, attracting claims and counter-claims about the authenticity of Josh, his band, and the project as a whole.

${ }^{6}$ Spencer McHugh, brand director of Orange, explained in 2010: 'We have a term we use internally about being 'effortlessly digital,' which is something we've been trying to do for the last couple of years, where the digital landscape, or digital media, affects everything we do. We want to continue to develop and grow that' (Farey-Jones, 2010).

\section{References}


Andrejevic, Mark (2003) Reality TV: The Work of Being Watched. Lanham: Rowman \& Littlefield.

Andrejevic, Mark (2009) 'Exploiting YouTube: Contradictions of User-Generated Labor,' in Pelle Snickars and Patrick Vonderau (ed) The YouTube Reader. Stockholm: National Library of Sweden, pp. 406-423.

Arvidsson, Adam (2008) 'The Ethical Economy of Customer Coproduction,' Journal of Macromarketing, 28 (4): 326-338.

Bjorkdahl, Joakim and Erik Brolin (2003) 'Competition Policy and Scenarios for European $3 G$ Markets,' Communications and Strategies, 51 (3) 2003: 21-34.

Boddy, William (2004) New Media and Popular Imagination. Oxford: Oxford University Press.

Brooker, Will (2010) “"Now You're Thinking With Portals”: Media Training for a Digital World,' International Journal of Cultural Studies 13 (6): 553-573.

Caldwell, John Thornton (2008) Production Culture. Durham: Duke University Press.

Carter, Steven (2009) Digital Britain. HM Goverment, Department of Business Innovation \& Skills and Department for Culture, Media \& Sport.

Costa, Marie-Lou (2010) 'Bride Vows to Carry on Regardless,' Marketing Week, 21 January. http://www.marketingweek.co.uk/bride-vows-to-carry-onregardless/3008868.article (accessed 10 March 2010). 
Dawson, Max (2007) ‘Little Players, Big Shows: Format, Narration and Style on Television’s New Smaller Screens,' Convergence, 13 (3): 231-50.

de Souza e Silva, Adriana (2006) 'From Cyber to Hybrid: Mobile Technologies as Interfaces of Hybrid Spaces,' Space and Culture,' 9 (3): 261-278.

Donaton, Scott (2004) Madison \& Vine: Why the Entertainment and Advertising Industries Must Converge to Survive. New York: McGraw-Hill.

European Commission (2008) 'Legal Framework for Mobile TV Networks and Services,'

http://eur-

lex.europa.eu/LexUriServ/LexUriServ.do?uri=CELEX:52008DC0845:EN:NOT (accessed 30 November 2010).

Evans, Elizabeth (2011) Transmedia Television. London: Routledge.

Farber, Alex (2009) 'You Tube Campaign Success Leads T-Mobile to up Digital Spend,' New Media Age. 5 February, p. 5.

Farey-Jones, Daniel (2010) 'Turning Geek into Brand Chic,' Marketing, 27 January, p. 24.

Grainge, Paul (2008) Brand Hollywood: Selling Entertainment in a Global Media Age. London: Routledge.

Grainge, Paul (2010) 'Elvis Sings for the BBC: Broadcast Branding and Digital Media Design,' Media, Culture \& Society, 32 (1): 45-61.

Jenkins, Henry (2006) Convergence Culture. New York: New York University Press. 
Harrison-Pepper, Sally (1991) Drawing a Circle in the Square: Street Performing in New York's Washington Square Park. Jackson: University Press of Mississippi.

Hespos, Tom (2003) 'Entertainment Advertising Moves the Needle,' iMediaConnection, http://www.imediaconnection.com/content/1995.imc (accessed 6 April 2004).

Hosea, Maeve (2008) 'Orange: A Ringing Endorsement of the Silver Screen,' Brand Strategy, 8 September, 48

Kennedy, Adam James (2009) Branded Art. Unpublished PhD dissertation, University of Kingston, UK.

Ling, Rich, and Jonathan Donner (2009) Mobile Communication. Cambridge: Polity Press.

Lotz, Amanda D. (2007) The Television Will be Revolutionized. New York: New York University Press.

May, Harvey, and Greg Hearn (2005) 'The Mobile Phone as Media,' International Journal of Cultural Studies, 8 (2): 195-211.

Nicholson, Judith A. (2005) 'Mobility, New Social Intensities and the Coordinates of Digital Networks,' Fibre culture, Issue 6. http://journal.fibreculture.org/issue6/ (accessed 17 February 2010)

OECD (2010) 'Indicators of broadband coverage,' OECD, Paris. http://www.oecd.org/sti/telecom [end 2008] (accessed 15 January 2010).

Rae Cooley, Heidi (2004) 'It's all about the Fit: The Hand, the Mobile Screenic Device and Tactile Vision,' Journal of Visual Culture 3 (2): 133-155. 
Rheingold, Howard (2002) Smart Mobs: The Next Social Revolution. Cambridge: Perseus.

Peters, Kathrin and Andrea Seier (2009) 'Home Dance: Mediacy and Aesthetics of Self on YouTube,' in Pelle Snickars and Patrick Vonderau (eds) The YouTube Reader. Stockholm: National Library of Sweden, pp. 187-203.

Saatchi \& Saatchi (2009) 'Saatchi \& Saatchi create dance mania at Liverpool St Station.' Press release, 26 January. http://www.saatchi.co.uk/news/archive (accessed 10 March 2010).

Spurgeon, Christina (2008) Advertising and New Media. London: Routledge.

Tilson, David and Kalle Lyytinen (2006) 'The 3G Transition: Changes in the US Wireless Industry,' Telecommunication Policy 30 (10-11): 560-586.

Walker, Rob (2003) 'We're all connected?' New York Times Magazine, 24 August, p. SM11. 
